\title{
Factors influencing natural regeneration of totara (Podocarpus totara D.Don) on grazed hill country grassland in Northland, New Zealand
}

\author{
David O Bergin ${ }^{*}$ and Mark O Kimberley ${ }^{2}$
}

\begin{abstract}
Background: There is increasing interest in establishing indigenous forests on marginal pastoral hill country in New Zealand to improve soil conservation, water quality and indigenous biodiversity. Large-scale reforestation using native seedlings is extremely costly. However, given suitable seed sources, it is possible to encourage natural regeneration of grassland into native plants.

Methods: A grazed, sloping pasture site in Northland where totara (Podocarpus totara D.Don) regeneration had been allowed to develop over a 10-year period was assessed using a grid of 2-metre diameter plots. Counts of regenerating woody species and cover of herbaceous species were obtained in each plot. Plots were classified on the basis of herbaceous species cover using the TWINSPAN classification procedure. Regression analyses were used to identify site factors and characteristics of the herbaceous vegetation associated with totara regeneration.

Results: More than 7,000 stems ha ${ }^{-1}$ of woody species, mostly totara and gorse (Ulex europaeus L.), had accumulated over the 10-year period despite the presence of cattle grazing. Regeneration of totara was associated with steeper slopes and sites with the greatest diversity of herbaceous species but with lower overall levels of herbaceous cover. The regeneration pattern of the other main woody species was similar although gorse colonised a wider range of sites. Regeneration of woody species was absent on flatter sites, which were dominated by a few high-fertility tolerant herbaceous species and had high levels of herbaceous cover.

Conclusion: This study has shown that regeneration of totara on a pastoral hill-country site was most prevalent on steeper slopes of lower fertility with typically sparse vegetation cover comprising low fertility tolerant herbaceous species. Conversely, totara regeneration was absent on flatter areas of higher fertility. It seems likely that grazing assists totara regeneration by keeping pasture cover short, thus increasing light levels near ground level for newly germinated seedlings. The propensity for totara to regenerate on pastoral hill country in the presence of grazing and where there is a nearby seed source could provide a practical option for re-establishing indigenous woody vegetation on erosion-prone marginal land.
\end{abstract}

Keywords: Indigenous; Podocarpus totara; Ulex europaeus; Natural regeneration; Pastoral farming; Grazing; Hill country

\footnotetext{
* Correspondence: davidbergin.erl@gmail.com

'Environmental Restoration Ltd, 53 Te Puea Road, RD4, Rotorua, New

Zealand

Full list of author information is available at the end of the article
} 


\section{Background}

There is increasing interest in establishing indigenous forests on marginal pastoral hill country in New Zealand to improve soil conservation, water quality and indigenous biodiversity. In recent years, major rainstorm events in the North Island's East Coast, Bay of Plenty, Wairarapa and Manawatu regions have caused soil loss over extensive areas of steep erosion-prone pasture land, contributing to sedimentation of river systems and widespread flood damage to public and private assets (Davis et al. 2009). These events have highlighted the desirability of afforesting erosion-prone grasslands to reduce soil loss and flood damage. Indigenous tree and shrub species can provide good protection against erosion (Bergin et al. 1995, Marden and Rowan 1993, Rowe et al. 1999), although fast-growing exotic tree species such as Pinus radiata D.Don are more often advocated for such purposes.

Large-scale reforestation using native seedlings is extremely costly, with costs ranging from $\$ 15,000 \mathrm{ha}^{-1}$ for bare-root stock through to $\$ 35,000 \mathrm{ha}^{-1}$ for containergrown stock (Davis et al. 2009). Potentially less costly systems for establishing indigenous trees and shrubs on grasslands have been advocated such as direct seeding using manuka (Leptospermum scoparium J.R.Forst. et G. Forst. var. scoparium) or kanuka (Kunzea ericoides (A. Rich) Joy Thomps. var. ericoides). However, the most critical requirements for direct seeding are the elimination of competing vegetation, especially grasses, and the maintenance of a microclimate suitable for seed germination and growth (Porteus 1993, Ledgard et al. 2008). Experience indicates that both of these requirements are very difficult to achieve in practice on typical grassland sites (Davis et al. 2009). It is possible to encourage natural regeneration to convert grassland into indigenous plants where there are adjacent areas of suitable seed sources. Requirements are similar to those of direct seeding but there must also be an adequate local seed source (Davis et al. 2009). Porteus (1993) describes a system involving the removal of grass to allow natural regeneration of indigenous seedlings, followed by hand thinning of weed species, and continued protection of selected seedlings from grazing or browsing animals. However, this system would be too labour intensive to be applied on a large scale.

Indigenous tree and shrub species can sometimes regenerate naturally in grassland in New Zealand, given the right conditions. This has been studied extensively (e.g. Bergin 2000, Bergin et al. 1995; Bergin and Gea 2007; Sullivan et al. 2007), and is reviewed by Davis et al. (2009). Natural regeneration of kanuka and manuka which have wind-dispersed seed, and of totara (Podocarpus totara D.Don) which has bird-dispersed seed, is common where seed sources are available and when management inputs such as weed control and fertiliser application have been reduced.
Regenerating stands of totara are found in many grazed pastoral areas throughout New Zealand (Wardle 1974). They occur as groves or as scattered trees along fencelines and roadsides (Esler 1978), or as more extensive regenerating stands on hill country, and along riparian areas and on river flats, sometimes mixed with kahikatea (Dacrycarpus dacrydioides (A. Rich.) de Laub.) (e.g., Duguid 1990). Regeneration occurs within grass to form pure stands of totara or can be in varying mixtures with other species including gorse (Ulex europaeus L.), manuka and kanuka.

It is generally considered important in indigenous forest establishment to exclude grazing and browsing animals, and rehabilitation of indigenous forest remnants in grassland landscapes can often be achieved simply by excluding livestock and animal pests (Davis et al. 2009). However, several studies indicate that a number of less palatable indigenous species including totara, manuka and kanuka can successfully regenerate in the presence of grazing animals. For example, Miller and Wells (2003) found that grazing appears to improve site availability for totara establishment on river terraces in south Westland. Regenerating totara is often observed on farmland in Northland when there is a local seed source (Bergin 2000). A survey using high-resolution aerial photography in the Whangaroa County in Northland identified a substantial regional resource of regenerating totara on farmland (Quinlan 2009).

The current study was undertaken at a typical Northland farmland site where early-stage totara regeneration was observed to be occurring despite an active cattle-grazing regime. This site provided the opportunity to study (i) whether totara can regenerate naturally on a grassland site subject to intensive grazing pressure, and (ii) if so, to identify site factors and characteristics of the vegetation associated with such totara regeneration.

\section{Methods \\ Site description}

The study site is located on pastoral hill country within the Whangaroa County on the east coast of the Far North district in Northland (NZTM 1671325E, 6108400 N). The area surrounding the site comprises ridges and hill slopes dominated by exotic pasture grasses and mostly fenced-off riparian areas with mixtures of naturally regenerating indigenous forest species and small stands of planted exotic trees. Groves dominated by regenerating totara occur on steep slopes along with scattered totara and kahikatea trees within and immediately adjacent to the trial site, some of which were observed to be seeding.

The site consists of a predominantly south-east facing slope of over $40^{\circ}$ in places, within a large paddock dominated by exotic pasture species. The soils of the rolling 
and hill land are Otangaroa clay and sandy clay loams (Sutherland et al. 1980) taxonomically described as 'wet soils' of podzolised yellow-brown earths (Hewitt 1998). The soils of the flood plains at the base of the ridge are Whakapara silt loam and clay loam, which are well to moderately well-drained 'recent soils' (Sutherland et al. 1980) now classed as Mottled Fluvial Recent soils that have been derived from river alluvium (Hewitt 1998). The elevation of the site is $20 \mathrm{~m}$ above sea level. The nearest weather station to Kaeo located at Kerikeri $25 \mathrm{~km}$ to the south has an average annual rainfall of $1682 \mathrm{~mm}$, a daily mean temperature of $15.2^{\circ} \mathrm{C}$, an average of 25 ground frosts per year and an average of 2000 sunshine hours per year (New Zealand Meteorological Service 1983).

The study site had not been cleared of regenerating totara over the preceding 10 years. The only weed management had been an annual spot spraying of scattered gorse that had grown up to 1-m high using the herbicide triclopyr $\left(\right.$ Grazon $\left.^{\mathrm{Tx}}\right)$ at the label rate for gorse application (Doug Lane, landowner, pers. comm.). Totara and other woody native species were not targeted. The site had been regularly grazed by cattle using a beef-raising regime achieving $800 \mathrm{~kg}$ live weight per ha per year, estimated by the landowner to approximate 11 stock units per ha (ewe equivalents). This intensive grazing regime comprised break-feeding using portable electric fencing on a 35-day rotation over summer (October-April) and 70-day rotation over winter (May-September). As part of standard farm practice the site had been top-dressed annually with reactive rock phosphate with potassium at $350 \mathrm{~kg}$ per ha. Lime had been applied at 2.5 tonnes per ha once every four years. Fertiliser and lime were applied by truck traversing the flat and rolling terrain with some associated dispersal onto steeper hill slopes (Doug Lane, pers. comm.).

\section{Field sampling}

A rectangular $120 \mathrm{~m} \times 50 \mathrm{~m}$ area was demarcated to encompass a hill slope from base to ridge crest as the study area. Within this area, lines were marked at 4-m intervals across the slope, and two-metre diameter circular plots established and marked at 4-m intervals along each line. The resulting 347 plots formed a $4-\mathrm{m} \times 4 \mathrm{~m}$ grid covering the area.

Within each plot, seedlings and saplings within six height categories were recorded for all woody species present, including totara, kahikatea, gorse and manuka/ kanuka (considered too difficult to distinguish apart at small seedling stage) and small quantities of a few other indigenous tree and shrub species. Height categories used for the woody species were $0-10 \mathrm{~cm},>10-30 \mathrm{~cm}$, $>30-100 \mathrm{~cm},>1$ to $2 \mathrm{~m},>2$ to $5 \mathrm{~m}$ and $>5 \mathrm{~m}$.
Percentage cover scores were obtained for herbaceouscover species which included grasses, ferns, dicotyledons, rushes and a sedge, based on a modified BraunBlanquet cover scale (Mueller-Dombois and Ellenberg 1974). Vegetation cover classes recorded separately for each species were: $1,<1 \% ; 2,1-5 \% ; 3,6-25 \% ; 4,26-50 \%$; $5,51-75 \% ; 6,76-95 \% ; 7,>95 \%$. The overall vegetation cover (PCTCOV) and area in bare ground (PCTBARE) were also determined for each plot using the same sevenpoint scale. Fertility tolerances of herbaceous pasture cover species were obtained from several sources (e.g. Daly 1973; Lambrechtsen 1975; Levy 1970; Parham and Healy 1976). On the basis of these, all major non-woody species found in the study were classified into one of three fertility tolerance classes (High, Medium, Low). A variable representing fertility tolerance was obtained from the summed cover percentages (using midpoints for each cover class) of High and Low fertility tolerant species: $\mathrm{FERT}=\%$ High $/(\%$ High $+\%$ Low $)$.

Site factors recorded for each plot included aspect, slope angle, degree of disturbance of the soil profile by cattle and any recent browsing and trampling damage to woody vegetation. The area was mapped in relation to nearby semi-mature totara and other tree species, and evidence of seeding of totara within and in the vicinity of the survey site during autumn and winter was noted. The landowner was interviewed to ascertain the history of site management and current farming practices that were relevant to the vegetation cover over the survey site.

\section{Data analysis}

Classification of plots based on the cover class of each herbaceous species was carried out using the TWINSPAN procedure (Hill 1979) as implemented in the PCORD Version 4 software package. TWINSPAN applies a polythetic divisive technique of indicator species analysis (ISA) (Hill et al. 1975). TWINSPAN divisions were taken to the second level classifying the plots into four groups.

TWINSPAN groups were compared for the following variables:

- Presence/absence of each major herbaceous species

- Presence/absence of each major woody species (totara, gorse, manuka/kanuka, kahikatea)

- NSPECIES - the number of species present (representing a species richness score)

- PCTCOV - percentage herbaceous cover

- PCTBARE - percentage bare ground

- SLOPE - slope angle $\left({ }^{\circ}\right)$

- FERT - fertility tolerance of herbaceous vegetation, $\% \mathrm{High} /(\%$ High +\%Low)

These comparisons were made using one-way analyses of variance (ANOVAs) carried out using the GLIMMIX 
procedure in the SAS Version 9.2 data analysis package. Presence/absence variables were assumed to follow the binomial distribution and were fitted using logit link functions while other variables were assumed to be normally distributed. Pair-wise comparisons between groups were performed using the Tukey-Kramer method.

One of the problems inherent in an observational study such as this is that the plots cannot be considered to be spatially independent, and standard statistical tests may, therefore, tend to overstate levels of significance. An attempt was made to account for this by including exponential spatial covariance structures in all the ANOVAs. This generally resulted in considerable reductions in levels of significance when compared with simple ANOVAs, but it was assumed that this analysis approach provided a truer reflection of the significance of each variable.

Associations between totara regeneration and various environmental variables were estimated by calculating Pearson correlation coefficients. A series of logistic regression models were fitted using the GLIMMIX procedure to test these associations. These models used presence/absence of totara as the dependent variable, and were fitted using a binomial distribution and logit link function that included an exponential spatial covariance error structure. Independent variables fitted in these regressions were: SLOPE, PCTCOV, PCTBARE, NSPECIES, FERT, presence of other major woody species, and TWINSPAN group (fitted as a categorical variable). Stepwise multiple regression models were also fitted using the above variables.

\section{Results}

The equivalent of over 7,000 stems ha ${ }^{-1}$ of woody species, split almost evenly between totara and gorse with a few other minor species, were found regenerating on this Northland grassland site (Table 1). Totara was found in about a quarter of the plots surveyed with a high proportion (73\%) of totara plants being less than $1 \mathrm{~m}$ high, indicating that recruitment was continuing. Kanuka/ manuka and kahikatea were present in $4-5 \%$ of plots amounting to less than 400 stems ha ${ }^{-1}$ across the study site for each, all in the lower size classes. The broadleaved shrub species mingimingi (Leucopogon fasciculatus (G.Forst.) A.Rich.), mahoe (Melicytus ramiflorus J.R.Forst. et G.Forst.) and towai (Weinmannia silvicola Sol. ex A. Cunn.) were found growing within dense clusters of totara saplings protected from browsing and amounted to less than 18 stems ha ${ }^{-1}$.

A total of 48 herbaceous species were identified at the site (Additional file 1: Table S1). High and medium fertility-tolerant species were predominantly on flatter sites, while medium to low fertility-tolerant species were predominantly on steeper sites along with the major woody species totara and gorse (Figure 1). Plots were classified into four groups on the basis of herbaceous species composition using TWINSPAN (Additional file 2: Table S2). Group 1 plots were predominately on flatter sites with improved pasture species mostly of high fertility tolerance. Groups 2 and 3 were generally on sites of intermediate slope and contained increasing numbers of species of medium or low fertility tolerance. Group 4 plots tended to be on the steepest slopes and often contained common weed species of low or medium fertility tolerance. There was little difference in herbaceous species richness between the TWINSPAN groups at the plot scale $\left(\sim 3 \mathrm{~m}^{2}\right)$. However species richness increased with increasing sampling effort with Group 1 showing the least richness and Group 4 the greatest richness. The mean number of herbaceous species in 20 randomly chosen plots ranged from 14.8 (Group 1) to 28.0 (Group 4) with the other groups being 20.4 (Group 2) and 21.1 (Group 3).

There were significant differences in: the presence of woody species, mean herbaceous cover and mean slope among the TWINSPAN groups (Table 2). Woody species were found mostly in Groups 3 and 4 where percentage mean herbaceous cover was significantly lower and mean slope significantly steeper than in Groups 1 and 2 . Gorse was most frequent in Group 3 where it was

Table 1 Abundance and size class of the woody species regenerating amongst herbaceous pasture species

\begin{tabular}{|c|c|c|c|c|c|c|c|c|}
\hline \multirow[t]{2}{*}{ Species } & \multirow{2}{*}{$\begin{array}{l}\text { Number of } \\
\text { stems ha }^{-1}\end{array}$} & \multirow{2}{*}{$\begin{array}{l}\text { Plots with at } \\
\text { least one plant } \\
\text { present (\%) }\end{array}$} & \multicolumn{6}{|c|}{ Percentage of plants in each size class } \\
\hline & & & $0-10 \mathrm{~cm}$ & $11-30 \mathrm{~cm}$ & $31-100 \mathrm{~cm}$ & $>1-2 \mathrm{~m}$ & $>2-5 \mathrm{~m}$ & $>5 \mathrm{~m}$ \\
\hline Totara & 3422 & 23.6 & 19 & 21 & 34 & 18 & 7 & 1 \\
\hline Gorse & 3036 & 35.2 & 12 & 37 & 46 & 5 & 0 & 0 \\
\hline Kahikatea & 367 & 4.9 & 39 & 28 & 27 & 3 & 3 & 0 \\
\hline Manuka/kanuka & 385 & 3.7 & 64 & 33 & 3 & 0 & 0 & 0 \\
\hline Mingimingi & 9 & 0.3 & 0 & 100 & 0 & 0 & 0 & 0 \\
\hline Mahoe & 18 & 0.6 & 0 & 0 & 0 & 100 & 0 & 0 \\
\hline Towai & 9 & 0.3 & 0 & 100 & 0 & 0 & 0 & 0 \\
\hline TOTAL & 7247 & & & & & & & \\
\hline
\end{tabular}




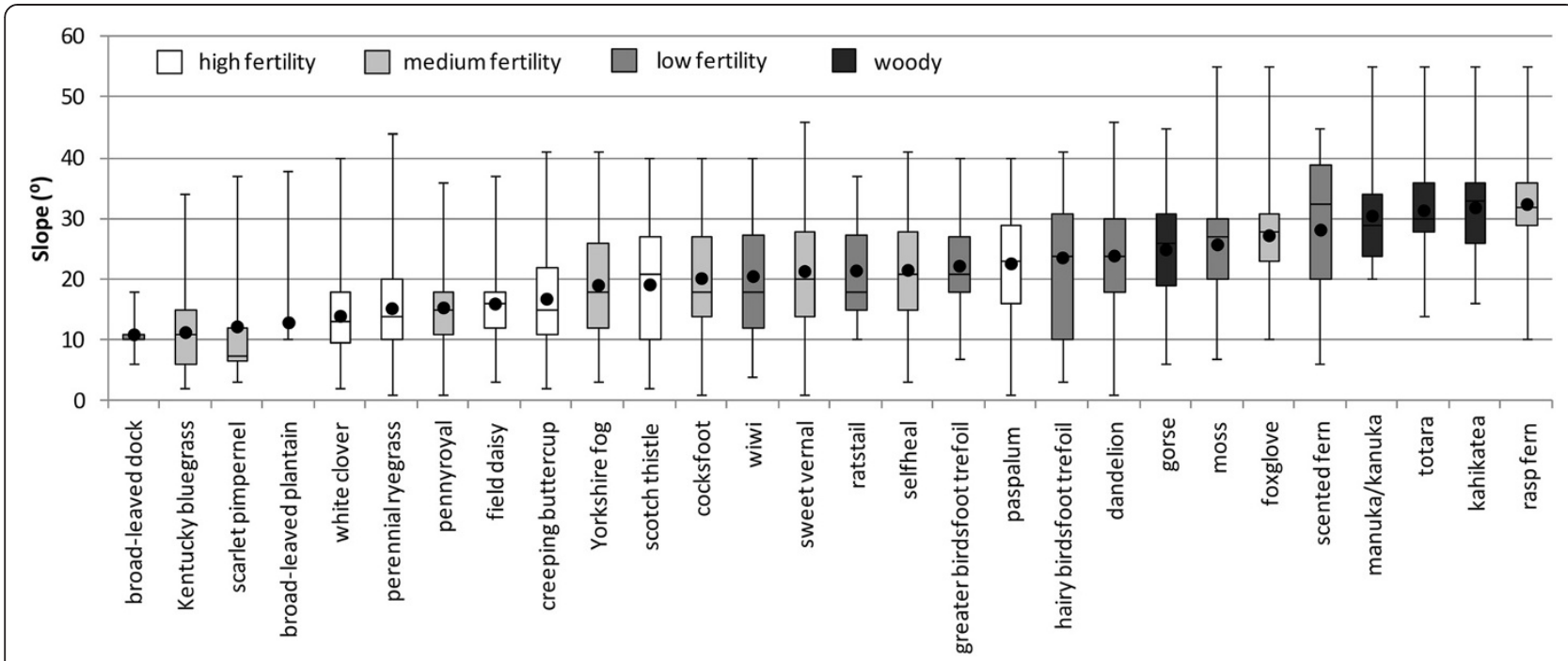

Figure 1 Box and whisker plots showing distribution of slope in plots where each species was present. The upper and lower edges of each box indicate the upper and lower quartiles of the slope distribution, the centre line indicates the median, the whiskers indicate the maximum and minimum slopes, and the dot indicates the mean slope. Species are ordered on the basis of mean slope from lowest to highest. Herbaceous species with mean cover more than $5 \%$ are shown along with the four most prevalent woody species. Fertility tolerance classes of herbaceous species are also shown.

present in nearly $60 \%$ of plots. In contrast, there were no woody species present on the relatively flat Group 1 sites where mean herbaceous cover was highest at $94 \%$. Similarly, the gently sloping Group 2 sites had a low number of woody species but a high percentage of herbaceous cover.

Correlation and logistic regression analysis identified several variables which were strongly indicative of the presence or absence of totara (Table 3). Totara was most likely to be present on steeper slopes and on sites with relatively low percentage mean grass cover. These results are illustrated in Figures $2 \mathrm{a}$ and $2 \mathrm{~b}$ where mean percentage presence of totara is plotted against slope classified into four classes, and overall herbaceous cover in the Braun-Blanquet cover-scale classes. The combined effect of slope and herbaceous cover is shown using simplified

Table 2 A comparison of the presence of four woody species, mean herbaceous cover and mean slope across the four TWINSPAN groups

\begin{tabular}{lrrrr}
\hline Variable & \multicolumn{4}{c}{ TWINSPAN group } \\
\cline { 2 - 5 } & $\mathbf{1}$ & $\mathbf{2}$ & $\mathbf{3}$ & $\mathbf{4}$ \\
\hline Totara presence (\%) & $0 \mathrm{a}$ & $4 \mathrm{a}$ & $29 \mathrm{~b}$ & $48 \mathrm{~b}$ \\
Gorse presence (\%) & $0 \mathrm{a}$ & $8 \mathrm{a}$ & $59 \mathrm{~b}$ & $39 \mathrm{~b}$ \\
Manuka/kanuka presence (\%) & $0 \mathrm{a}$ & $0 \mathrm{a}$ & $1 \mathrm{a}$ & $15 \mathrm{~b}$ \\
Kahikatea presence (\%) & $0 \mathrm{a}$ & $1 \mathrm{a}$ & $0 \mathrm{a}$ & $23 \mathrm{~b}$ \\
Mean herbaceous cover (\%) & $94 \mathrm{a}$ & $83 \mathrm{~b}$ & $56 \mathrm{c}$ & $46 \mathrm{~d}$ \\
Mean slope $\left(^{\circ}\right)$ & $8 \mathrm{a}$ & $13 \mathrm{~b}$ & $24 \mathrm{c}$ & $26 \mathrm{c}$ \\
\hline
\end{tabular}

Within each row, values followed by the same letter do not differ significantly $(p=0.05)$. classes in Figure 2c. This shows that totara was almost entirely absent on sites with slope less than $20^{\circ}$ and herbaceous cover greater than $50 \%$, but on steeper sites it was strongly associated with lower levels of herbaceous cover. Totara was also more common where other woody species (such as gorse) were regenerating, and in plots dominated by herbaceous species more tolerant of lower-fertility sites such as those in TWINSPAN Groups 3 and 4 (Figure 2d).

A stepwise multiple logistic regression model for the presence of totara included the following independent variables (in order): SLOPE (positive), PCTCOV (negative) and NSPECIES (positive). All three variables were statistically highly significant $(p<0.0001)$ with no further independent variable significant at the $5 \%$ level.

Table 3 Tests of association between presence/absence of totara and various environmental variables

\begin{tabular}{lrrr}
\hline Variable & Correlation & F value & Pr $>$ F \\
\hline SLOPE $\left(^{\circ}\right.$ ) & 0.64 & 93.09 & $<0.0001$ \\
PCTCOV (\% herbaceous cover) & -0.52 & 49.70 & $<0.0001$ \\
PCTBARE (\% Bare ground) & 0.27 & 8.51 & 0.0038 \\
Gorse present (\%) & 0.25 & 5.77 & 0.017 \\
Manuka/kanuka present (\%) & 0.25 & 7.29 & 0.0073 \\
FERT (\%High/(\%Low +\%High)) & -0.39 & 16.31 & $<0.0001$ \\
NSPECIES (no. herbaceous species) & 0.31 & 16.12 & $<0.0001$ \\
TWINSPAN group & - & 5.59 & 0.0009 \\
\hline
\end{tabular}

Shown are the Pearson correlation coefficient, and the significance of the association tested using logistic regression $\mathrm{F}$ values (with 1 and 345 degrees of freedom) and probabilities. 


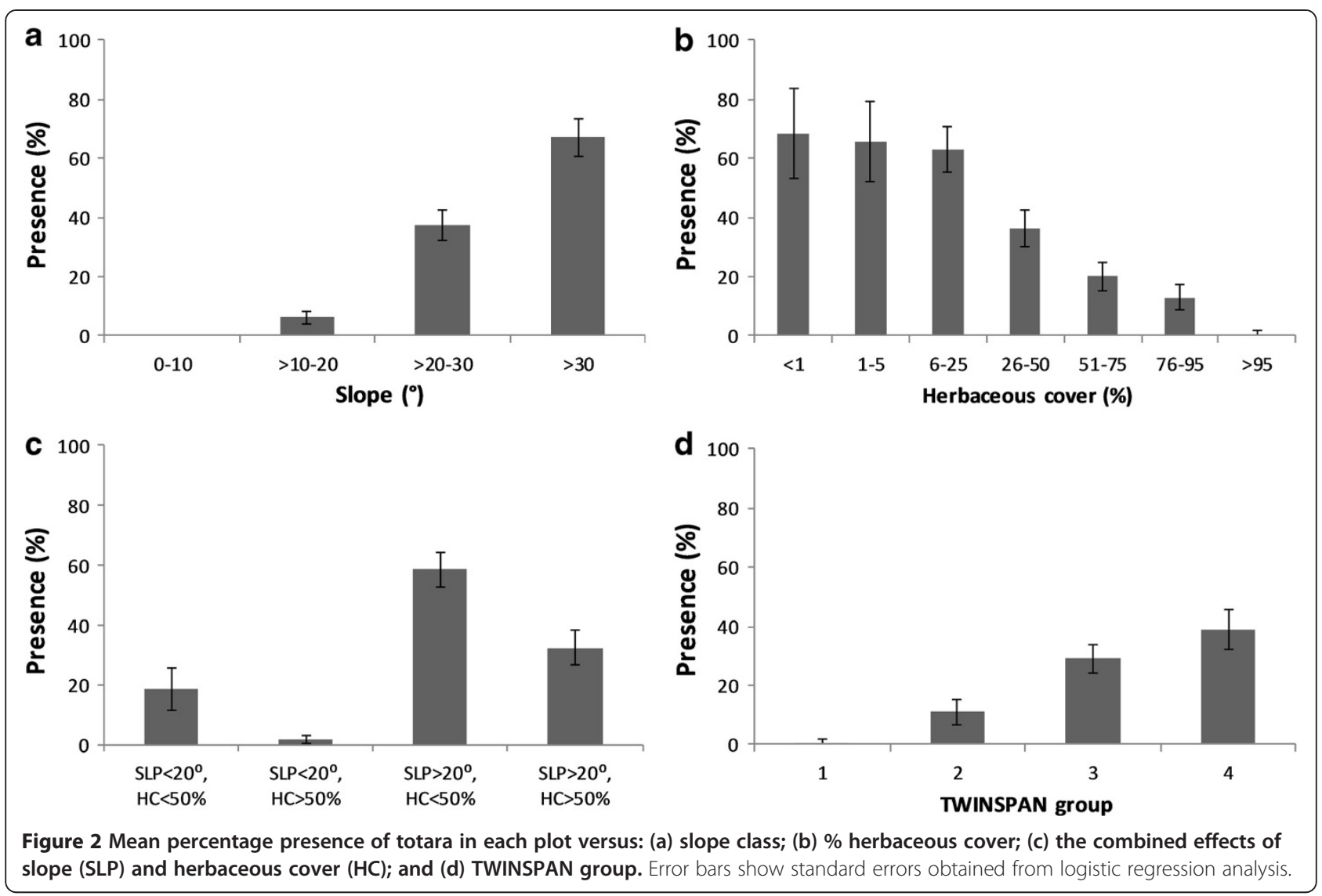

A map showing locations of plots with slope $>20^{\circ}$ shows that the study side contained a roughly crescentshaped sloping area with flat zones below and above this area (Figure 3). Regenerating totara was almost entirely absent in the flat areas. Totara was present in several large contiguous zones within the sloping area, but was absent from other parts of the slope. An examination of the sloped area (plots with slope $>20^{\circ}$ ) found that $56 \%$ of plots without totara had high levels of herbaceous cover $(>50 \%)$ compared with only $27 \%$ of plots with totara. This suggests that competition from grasses was a major factor hindering the establishment of totara in the sloped area.

\section{Discussion}

It is not surprising that totara and gorse were the dominant regenerating woody species on this pastoral hillcountry site in Northland as both are light-demanding pioneer species that readily establish in grass and are relatively unpalatable to grazing stock (e.g., Ebbett and Ogden 1998; Zabkiewicz 1976). Successful regeneration of totara has occurred despite intensive cattle grazing.

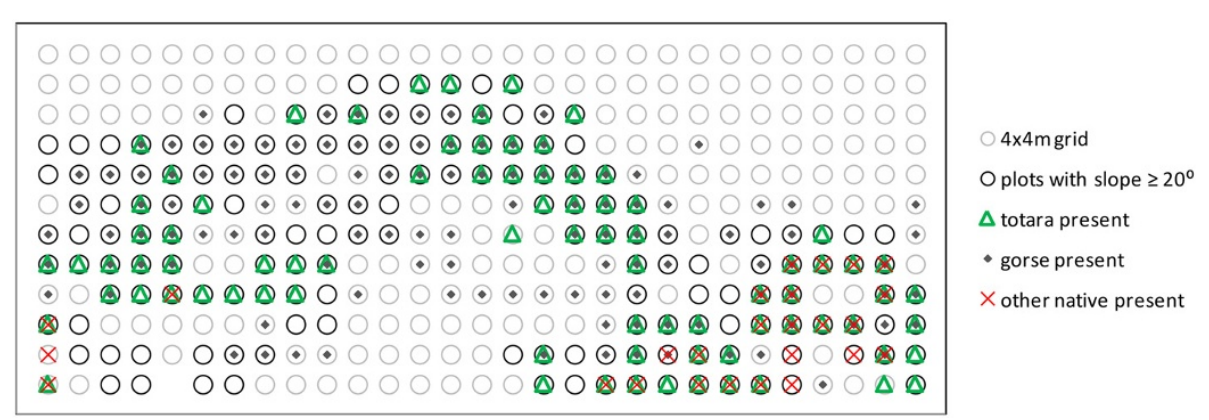

Figure 3 Simplified map of study site showing plots with slope greater or equal to $20^{\circ}$, plots with totara present, plots with other woody native species present, and plots with gorse present. 
Totara has also been found to colonise pastures elsewhere in the North and South Islands (e.g. Beveridge 1977, Wardle 1974, Miller and Wells 2003). Regeneration of totara also occurs in open seral vegetation, such as under a light canopy of manuka and kanuka (Wardle 1991). These and other studies indicate that totara is light-demanding, tolerant of dry exposed sites and that regenerating totara plants are not particularly palatable to livestock.

The pattern of regeneration of totara on farmland in Northland is consistent with the 'catastrophic' regeneration mode (Veblen 1992) where an even-aged stand develops after a massive disturbance such as fire, mass movement, flooding, large-scale windthrow or volcanic eruption. Seedlings of species that adopt this mode are typically shade-intolerant. Ebbett and Ogden (1998) showed that totara and kahikatea display the greatest height growth responses to increased light compared with the other major podocarps matai (Prumnopitys taxifolia (D.Don) de Laub.), rimu (Dacrydium cupressinum Lamb.) and miro (Prumnopitys ferruginea (D.Don) Laubenf.). Clearance of forest cover for farming has resulted in similarly catastrophic disturbance and consequently, shade-intolerant species such as totara and kahikatea are successful colonisers on farmed sites (Burns 2000).

Totara regeneration was associated with steeper slopes and sites with greater diversity of herbaceous species but with lower levels of herbaceous cover. These steeper slopes have less herbaceous vegetation cover with species of lower fertility tolerance, possibly because the soils are less fertile, but also because of footfalls and skidding by cattle when compared with adjacent flatter sites. It is this combination of less grass competition and highly disturbed microsites prone to drought which favours establishment of totara and other woody pioneer species. In contrast, managed highly productive grass swards dominated by perennial ryegrass and clover, which are common on fertile soils throughout the country, are effective in preventing reversion to woody vegetation (Levy 1970).

Totara regeneration is occurring at this site despite intensive grazing by cattle on a regular basis during the 10 -year period prior to the study. Although there was no ungrazed control site for comparison, some reasonable conclusions can be made regarding the role played by grazing cattle in the successful regeneration of totara at this site. It seems likely that grazing has assisted regeneration by keeping grass cover short, thus increasing light levels near ground level for newly germinated seedlings. Miller and Wells (2003) cited several New Zealand studies demonstrating the reduced ability of native woody seedlings to establish and survive through rank grass. On grazed land leased from the Department of Conservation in south Westland, Buxton et al. (2001) found there were higher numbers of seedlings of a particular variety of totara (Podocarpus totara var. waihoensis Wardle) in grazed plots than in plots within fenced exclosures. They suggested that cattle may be removing the more palatable herbaceous and woody species reducing competition for the less palatable canopy-formers and, to some extent, facilitating their recruitment.

On sloping ground, particularly when wet, footfalls of cattle churn up the soil profile and prevent development of a dense ground cover of grass. Sheath and Carlson (1998) found damage to the soil surface was greatest on animal tracks and camps on moderate slopes, with high levels of disturbance to the soil surface due to skid damage on steep inter-tracks in hill country during winter. Although not quantified directly in the current study, considerable skid damage was evident on steep faces between animal tracks, resulting in a greater proportion of bare ground on steep slopes compared with flat sites. Many seedlings had established on the bare ground and less densely vegetated steep faces between formed animal tracks. Although trampling by livestock can severely damage young totara (Bergin and Pardy 1987), the present study shows that many seedlings are able to survive and develop on the steeper hill faces.

Further evidence of the influence of dense grass competition on germination of woody native species can be seen in direct seeding trials of various indigenous woody species on steep hill country grassland, which indicates the need to control intense competition from existing vegetation, particularly exotic grasses (Davis et al. 2009). For example, Ledgard et al. (2008) found that seedlings of indigenous species germinated from broadcast seeding in direct-seeding trials where soil had been disturbed. Further direct-seeding work indicated seedling establishment was best in ploughed/cultivated treatments, especially where rank grass had been mown and sprayed with herbicide beforehand (Davis et al. 2009).

Grazing maintains a light cover of grass and, on steep slopes, creates bare ground from animal disturbance. It also eliminates regeneration of palatable species such as hardwood trees and shrubs, some of which would otherwise regenerate quickly on these sites, competing with totara and slowing its establishment. Wardle (1991) indicated that seral shrubs and trees can form selfperpetuating communities where grazing eliminates tree seedlings of more palatable species. The unpalatable shrubs manuka and gorse, and the trees kanuka and totara clearly have an advantage on these grazed pasture sites in Northland. No other forest tree species have a chance to regenerate under a regime of continuous grazing.

Esler (1967) regarded the effects of grazing in the conversion of grassland to shrubland on Kapiti Island as 
diverse. Grazing either accelerates or retards succession of woody species depending on certain other site factors and can also determine which species are likely to succeed. He found that small areas of grassland remained on parts of Kapiti Island where heavy grazing occurred or where there was no grazing at all. Intensive grazing of pasture on fertile soils retarded the appearance of woody species but on other sites the invasion of manuka and kanuka ceased when sheep and goats were removed due the development of a dense deep turf. In management of hill country for pasture, intensity of grazing is a major factor in succession of woody species (Levy 1970). Sheep and cattle grazing have different effects on reversion of hill country to woody species. Intense close grazing by sheep leads to invasion of manuka, hard fern and rushes whereas controlled grazing with cattle will maintain a permanent sward provided that clovers are kept growing strongly by applications of phosphate (ibid).

The current farm-management practices at the study site of intensive cattle grazing (break-feeding at 35-day rotations during summer and 70-day rotations during winter) and annual topdressing with fertiliser (and lime every four years) are effectively maintaining the cloverperennial ryegrass dominated pastures on the lower angle slopes and flats. The steeper slopes are, however, dominated by less fertility-demanding grass species and with grazing, this open cover is allowing regeneration of totara and other non-palatable seral species such as manuka and gorse.

Manuka and kanuka were only minor components of the regeneration at this site. However, observations of many farmland sites throughout Northland indicate that regeneration of totara can be in pure stands or in mixtures with manuka and kanuka as well as with gorse. Manuka in particular has long been known to be effective in colonising a wide range of soils where sites have been subject to forest clearance, grazing animals and fires (Cockayne 1928). Large-scale pasture reversion to dense manuka and kanuka communities in hill county on the East Coast of the North Island has been occurring over several decades (Bergin et al. 1995). Extensive regenerating manuka and kanuka following abandonment of previously farmed land in the Waitakere Range have also developed where there has been a long history of grazing and trampling by cattle (Esler and Astridge 1974). The lack of widespread kanuka or manuka regeneration at this site may simply reflect the specific environmental and climatic conditions during the 10 years prior to the study. Although manuka and kanuka have different ecologies, both have relatively light winddispersed seed. In contrast, the seed of totara (which is dispersed by birds when seed trees are present (Beveridge 1964)), is produced most years and can be formed on relatively young trees. It is therefore not surprising that the proportion of these three species can vary widely within regenerating areas.

Apart from totara, kahikatea was the only other podocarp species found regenerating on this Northland pasture site. Seed-producing trees of both totara and kahikatea were in close proximity to the study site. Differences in site requirements between the two species may explain the lesser abundance of kahikatea, with kahikatea favouring moister sites than totara (e.g. Wardle 1991). Differences in palatability to stock may also be a contributing factor.

The benefits of reforesting steeply sloping marginal farmland to reduce soil loss and flood damage, and to increase biodiversity, are well known (Davis et al. 2009). The present study demonstrates that totara-dominated stands can develop naturally in grassland and that totara readily establishes on slopes greater than $20^{\circ}$ without affecting flatter country. Such steeper slopes are where the risk of erosion is greatest and would therefore benefit most from conversion from grassland to woody vegetation. This study demonstrates there may be no need to completely retire such areas from grazing. In fact grazing appears to have assisted in the regeneration process at this site.

A major requirement is an adequate local seed source from established totara trees. Where this is not available, a long-term option for landowners is to establish banks of seed trees throughout areas where totara regeneration may be desired. Well-managed totara established on reasonable sites will produce viable seed within 10 years of planting (Bergin et al. 2008). The role of totara seed sources and the intensity of seedfall required to allow the species to regenerate naturally in grassland, including the potential to establish totara seed sources on key sites across marginal pastoral hill country, should be the subject of further research.

On some sites, periodic control of aggressive persistent weeds such as pampas (Cortaderia spp.) could assist regeneration and development of totara. Other early successional weed species (if present), such as gorse, are likely to be ultimately succeeded by totara (e.g., Wilson 1994). If a fully-stocked totara stand was desirable, large gaps within regenerating totara stands could be in-filled by planting nursery-raised seedlings or trialling the efficacy of transplanting small seedlings from adjacent overstocked areas. Nursery-raised totara seedlings are likely to be more susceptible to browsing than hardened naturally regenerating seedlings so may need temporary protection from grazing animals. When seedlings are well established, areas could be fenced off to encourage a more diverse range of native plants including more shade tolerant and palatable broadleaved tree species. If desired, developing totara stands can be managed by thinning and pruning at appropriate stages, potentially 
providing a valuable resource of timber for future generations.

\section{Conclusions}

This study has shown that regeneration of totara on a pastoral hill-country site is most prevalent on steeper slopes of lower fertility. These areas typically have a sparse vegetation cover comprising herbaceous species tolerant of lower fertility conditions. Conversely, totara regeneration is absent on flatter areas with high levels of herbaceous cover dominated by higher fertility tolerant species. It seems likely that grazing assists totara regeneration by keeping pasture cover short, thus increasing light levels near ground level for newly germinated seedlings. The propensity for totara and other non-palatable woody species such as manuka and kanuka to occupy steeper, less fertile hillslopes compared to more productive flatter areas provides a practical option of establishing woody vegetation on erosion-prone marginal pastoral land.

\section{Additional files}

Additional file 1: Table S1. Woody and herbaceous species ranked by percentage mean presence in the 347 survey plots.

Additional file 2: Table S2. Summary of herbaceous pasture species. For each species, the percentage of plots with the species present is shown for each TWINSPAN group. Within each row, values followed by the same letter do not differ significantly $(p=0.05)$. Also shown are the mean slope of plots where the species was present and the fertility tolerance of the species. Only species with mean presence $>5 \%$ are shown with species ranked from most to least abundant.

\section{Competing interests}

The authors declare that they have no competing interests.

\section{Authors' contributions}

DOB was the primary author, designed the trial, carried out the field work and assisted with the data analysis. MOK undertook the majority of the analyses and was a secondary author. Both authors read and approved the final manuscript.

\section{Acknowledgements}

Access to natural totara stands were greatly appreciated from former landowners Doug and Sally Lane. Jessamy Herbert and Heidi McGlone assisted with fieldwork. The authors are grateful for helpful comments from members of the Northland Totara Working Group and Tāne's Tree Trust, particularly Professor Warwick Silvester, Paul Quinlan, Peter Berg, Dr Thomas Paul, Professor David Norton, an anonymous referee who reviewed an earlier draft and the editors of the New Zealand Journal of Forestry Science.

\section{Author details}

${ }^{1}$ Environmental Restoration Ltd, 53 Te Puea Road, RD4, Rotorua, New

Zealand. ${ }^{2}$ Scion, Private Bag 3020, Rotorua, New Zealand.

Received: 5 March 2014 Accepted: 16 April 2014

Published online: 02 July 2014

\section{References}

Bergin, DO. (2000). Current knowledge relevant to management of Podocarpus totara for timber. New Zealand Journal of Botany, 38, 343-359.
Bergin, D, \& Gea, L. (2007). Native Trees - Planting and Early Management for Wood Production. In New Zealand Indigenous Tree Bulletin No. 3. Revised Edition. Rotorua, New Zealand: New Zealand Forest Research Institute.

Bergin, D, \& Pardy, G. (1987). Growing totara. New Zealand Tree Grower, $8(3), 68-70$

Bergin, DO, Kimberley, MO, \& Marden, M. (1995). Protective value of regenerating tea tree stands on erosion-prone hill country, East Coast, North Island, New Zealand. New Zealand Journal of Forestry Science, 25(1), 3-19.

Bergin, DO, Kimberley, MO, \& Low, C. (2008). Provenance variation in Podocarpus totara (D. Don): Growth, tree form and wood density on a coastal site in the north of the natural range, New Zealand. Forest Ecology and Management, 255(5), 1367-1378.

Beveridge, AE. (1964). Dispersal and destruction of seed in central North Island podocarp forests. Proceedings of the New Zealand Ecological Society, $11,48-55$.

Beveridge, AE. (1977). Native trees on the farm. Farm Forestry, 19(3), 58-70.

Burns, BR. (2000). Managing Planted Native Stands. What can we Learn from the Ecology of Natural Forests? In W. Silvester \& R. McGowan (Eds.), Native Trees for the Future (Proceedings of a Forum Held at The University of Waikato, Hamilton, 8-10 October 1999, pp. 47-50). Hamilton: University of Waikato.

Buxton, RP, Timmins, SM, Burrows, LE, \& Wardle, P. (2001). Impact of Cattle on Department of Conservation Grazing Leases in South Westland: Results from Monitoring 1989-99, and Recommendations. Science for Conservation 179. Wellington: Department of Conservation.

Cockayne, L. (1928). The Vegetation of New Zealand (2nd ed.). Leipzig: Engelmann.

Daly, GT. (1973). The Grasslands of New Zealand. In R. H. M. Langer (Ed.), Pastures and Pasture Plants (pp. 1-39). Wellington: A.H. and A.W. Reed.

Davis, M, Douglas, G, Ledgard, N, Palmer, D, Bhubaneswor, D, Paul, T, Bergin, D, Hock, B, \& Barton, I. (2009). Establishing Indigenous Forest on Erosion-Prone Grassland: Land Areas, Establishment Methods, Costs and Carbon Benefits. Report to the Ministry of Agriculture and Forestry. Rotorua, New Zealand: New Zealand Forest Research Institute Ltd.

Duguid, F. (1990). Botany of Northern Horowhenua Lowlands, North Island, New Zealand. New Zealand Journal of Botany, 28, 381-437.

Ebbett, RL, \& Ogden, J. (1998). Comparative seedling growth of five endemic New Zealand podocarp species under different light regimes. New Zealand Journal of Botany, 36, 189-201.

Esler, AE. (1967). The vegetation of Kapiti Island. New Zealand Journal of Botany, 5, 394-399.

Esler, AE, \& Astridge, SJ. (1974). Tea tree (Leptospermum) communities of the Waitakere Range, Auckland, New Zealand. New Zealand Journal of Botany, 12, 485-501.

Esler, AE, \& Botany of the Manawatu District, New Zealand. (1978). New Zealand Department of Scientific and Industrial Research, Information Series No. 127. Wellington: Government Printer.

Hewitt, AE. (1998). New Zealand Soil Classification. Landcare Research Science Series No. 1. Manaaki Lincoln: Whenua Press.

Hill, MO, Bunce, RGH, \& Shaw, MW. (1975). Indicator species analysis, a divisive polythetic method of classification and its application to a survey of native pinewoods in Scotland. Journal of Ecology, 63, 597-613.

Lambrechtsen, NC. (1975). What grass is that? New Zealand Department of Scientific and Industrial Research, Information Series No. 87. Wellington: Government Printer.

Ledgard, N, Charru, M, \& Davey, H. (2008). Establishing native species from seed within exotic grasslands. New Zealand Journal of Forestry, 53, 23-32.

Levy, EB. (1970). Grasslands of New Zealand (3rd ed.). Wellington: Government Printer.

Marden, M, \& Rowan, D. (1993). Protective value of vegetation on tertiary terrain before and during Cyclone Bola, East Coast, North Island, New Zealand. New Zealand Journal of Forest Science, 23, 255-263.

Miller, C, \& Wells, A. (2003). Cattle grazing and the regeneration of totara (Podocarps totara var. waihoensis) on river terraces, south Westland, New Zealand. New Zealand Journal of Ecology, 27(1), 37-44.

New Zealand Meteorological Service. (1983). Summaries of Climatological Observations to 1980. Wellington: New Zealand Meteorological Service Miscellaneous Publication 177.

Parham, BEV, \& Healy, AJ. (1976). Common Weeds in New Zealand. Wellington: Government Printer

Porteus, T. (1993). Native Forest Restoration. A practical guide for landowners. Wellington: Queen Elizabeth II National Trust. 
Quinlan, P. (2009). A Role for Totara in Rural Production Landscapes. In I. Barton, R. Gadgil, \& D. Bergin (Eds.), Managing of Native Trees - Towards a National Strategy (pp. 31-35). Proceedings of the Tane's Tree Trust 10th Anniversary Conference and Workshop Held at The University of Waikato, Hamilton, 18-20 November 1999. Hamilton: University of Waikato.

Rowe, LK, Marden, M, \& Rowan, D. (1999). Interception and throughfall in a regenerating stand of kanuka (Kunzea ericoides var. ericoides), East Coast region, North Island, New Zealand, and implications for soil conservation. Journal of Hydrology, 38(1), 29-48.

Sheath, GW, \& Carlson, WT. (1998). Impact of cattle treading on hill land 1 - soil damage patterns and pasture status. New Zealand Journal of Agricultural Research, 41(2), 271-278.

Sullivan, JJ, Williams, PA, \& Timmins, SM. (2007). Secondary forest succession differs through naturalised gorse and native kanuka near Wellington and Nelson. New Zealand Journal of Ecology, 31, 22-38.

Sutherland, CF, Cox, JE, Taylor, NH, \& Wright, ACS. (1980). Soil map of Whangaroa - Kaikohe Area (Sheets 04/05). North Island, New Zealand. Scale 1:100,000: New Zealand Soil Bureau Map 183.

Veblen, T. (1992). Regeneration Dynamics. In D. C. Glenn-Lewin, R. K. Peet, \&

T. T. Veblen (Eds.), Plant Succession Theory and Practice (pp. 152-187). London: Chapman and Hall.

Wardle, P. (1974). The Totara. In R. Knox (Ed.), New Zealand's Nature Heritage 1(13) (pp. 347-350). Hong Kong: Hamlyn.

Wardle, P. (1991). Vegetation of New Zealand. Cambridge: Cambridge University Press.

Wilson, HD. (1994). Regeneration of native forest on Hinewai Reserve, Banks Peninsula. New Zealand Journal of Botany, 32(3), 373-383.

Zabkiewicz, JA. (1976). The ecology of gorse and its relevance to New Zealand forestry. In The use of herbicides in forestry in New Zealand: Proceedings of F.R.I. Symposium No 18 (pp. 63-68). Rotorua: New Zealand Forest Service.

doi:10.1186/s40490-014-0013-8

Cite this article as: Bergin and Kimberley: Factors influencing natural regeneration of totara (Podocarpus totara D.Don) on grazed hill country grassland in Northland, New Zealand. New Zealand Journal of Forestry Science 2014 44:13.

\section{Submit your manuscript to a SpringerOpen ${ }^{\circ}$ journal and benefit from:}

- Convenient online submission

- Rigorous peer review

- Immediate publication on acceptance

- Open access: articles freely available online

- High visibility within the field

- Retaining the copyright to your article

Submit your next manuscript at $>$ springeropen.com 